\title{
New occurrences of mollusks from the Santa Marta and Snow Hill Island (Gamma Member) formations, Upper Cretaceous, James Ross Island, Antarctic Peninsula
}

\author{
Novas ocorrências de moluscos das formações Santa Marta e \\ Snow Hill Island (Membro Gamma), Cretáceo Superior, Ilha \\ James Ross, Península Antártica
}

\section{Nuevos registros de moluscos de las formaciones Santa Marta y Snow Hill Island (Miembro Gamma), Cretácico Superior, Isla James Ross, Península Antártica}

\author{
Roberto Videira-Santos \\ https:/ / orcid.org/0000-0002-6221-1693 \\ robvidsan@yahoo.com.br
}

Universidade Federal do Rio de Janeiro, Museu Nacional, UFRJ/ Universidade Federal Rural

do Rio de Janeiro, UFRRJ, Seropédica, RJ

Sandro Marcelo Scheffler https:/ / orcid.org/0000-0002-6965-4550 schefflersm@mn.ufrj.br Universidade Federal do Rio de Janeiro, Museu Nacional, UFRJ, Rio de Janeiro, RJ

Alexander Wilhelm Armin Kellner https:/ / orcid.org/0000-0001-7174-9447

kellner@mn.ufrj.br

Universidade Federal do Rio de Janeiro, Museu Nacional, UFRJ, Rio de Janeiro, RJ

\begin{abstract}
Although the fossil record from Antarctica is increasing continuously, there is still a great lack of knowledge regarding the past biodiversity of this continent. Here we present the first occurrences of the ammonoid Pseudophyllites? cf. latus in the Santa Marta Formation (Santonian-early Campanian) and the scaphopod Laevidentallium? sp. (Laevidentallidae) in the Gamma Member (late Campanian) of the Snow Hill Island Formation (late Campanian - early Maastrichtian). The presence of Laevidentalliidae in the Gamma Member characterizes the oldest occurrence of this family in Antarctica and it is apparently another taxon that originated in this continent and later migrated to lower latitudes.
\end{abstract}

Key words: Ammonoidea, Scaphopoda, Santonian-Campanian, Larsen Basin, Antarctica. 
Resumo: Embora o registro fóssil da Antártica esteja aumentando continuamente, ainda há uma grande falta de conhecimento sobre a biodiversidade do passado deste continente. Apresenta-se aqui as primeiras ocorrências do amonoide Pseudophyllites? cf. latus na Formação Santa Marta (Santoniano-Campaniano inicial) e do escafópode Laevidentallium? sp. (Laevidentallidae) no Membro Gamma (Campaniano tardio) da Formação Snow Hill Island (Campaniano tardio - Maastrichtiano inicial). A presença de Laevidentalliidae no Membro Gamma caracteriza a ocorrência mais antiga desta família na Antártida e é aparentemente mais um dos táxons que surgiu neste continente e posteriormente migrou para latitudes mais baixas.

Palavras-chave: Ammonoidea, Scaphopoda, Santoniano-Campaniano, Bacia de Larsen, Antártida.

Resumen: Los fósiles antárticos, a pesar de ser abundantes, aún son poco conocidos. Se presenta aquí la primera aparición de el ammonoideo Pseudophyllites? cf. latus en la Formación Santa Marta (Santoniense-Campaniense inicial) y el escafopodo Laevidentallium? sp. (Laevidentallidae) en el Miembro Gamma (Campaniense tardío) de la Formación Snow Hill Island (Campaniense tardío - Maastrichtiense inicial). La presencia de Laevidentalliidae en el Miembro Gamma caracteriza la ocurrencia más antigua de esta familia en la Antártida y aparentemente es uno de los taxones que apareció en este continente y luego migró a latitudes más bajas.

Palabras clave: Ammonoidea, Scaphopoda, Santoniense-Campaniense, Cuenca de Larsen, Antártida.

\section{INTRODUCTION}

Where exposed, the Antarctic sedimentary rocks from the Mesozoic and Cenozoic have proven to be quite fossiliferous (e.g., Olivero, 2012a; Zinsmeister, 1982) but there is still lots of work to be done before a more comprehensive picture of the paleobiodiversity of this continent can be established. Abundant occurrences of ammonoids have been documented especially from the James Ross area (Larsen Basin, James Ross Sub-Basin) (e.g., Olivero, 1992; Olivero, 2007; Olivero, 2012a, 2012b; Olivero \& Medina, 2000; Spath, 1953). Although these invertebrates have been studied in this region for more than a century (e.g., Kilian \& Reboul, 1909; Weller, 1903a, 1903b) further paleontological studies are needed considering that many areas are still relatively unexplored due to adverse climatic conditions and difficult logistics to carry out fieldwork.

Studies involving extinct Antarctic scaphopods are even more incipient than those of ammonoids, with the few available studies focusing on Cenozoic deposits (e.g., Stilwell \& Zinsmeister, 1992; Pugaczewska, 1984). Records of Cretaceous genera or species of scaphopods from Antarctica are restricted to the Karlsen Cliffs Member (late Campanian) of the Snow Hill Island Formation and the López de Bertodano Formation (Maastrichtian - Danian; Medina \& DelValle 1985; Stilwell, 2008; Stilwell \& Zinsmeister, 1987). Although there have been previous reports of scaphopods from the Santa Marta Formation (Santonian - early Campanian) at James Ross Island (e.g., Crame, Pirrie, Riding, \& Thomson, 1991; Scasso, Olivero, \& Buatois, 1991), no taxonomic descriptions were published so far. 
In this paper we record the first occurrence of ammonoid Pseudophyllites? cf. latus from the Santa Marta Formation (Santonian - early Campanian) and the scaphopod Laevidentalium? sp. from the Gamma Member (late Campanian) of Snow Hill Island Formation (late Campanian - early Maastrichtian) These specimens were collected by the first field expedition of the PALEOANTAR project (e.g., Kellner et al. 2011).

\section{GEOLOGICAL SETTING}

The James Ross Sub-Basin, part of the Larsen Basin (DelValle, Elliot, \& Macdonald, 1992), is located in the northeast of the Antarctic Peninsula and contains a significant Meso-Cenozoic sedimentary succession (Fig. 1), related to the Gondwanan break-up and subsequent development of a back-arc basin (Hathway, 2000).

Figure 1: A: sedimentary deposits of the Cretaceous/Paleogene outcrops of the James Ross Sub-Basin.

In detail, the region where the PALEOANTAR expedition was concentrated; B: simplified geological map of the Ulu Peninsula, showing outcrops of the Santa Marta and Snow Hill Island (Gamma Member) formations, as well as the collection areas of the studied fossils. B.A - represents field number point 02, Abernethy flats (Pseudophyllites? cf. latus); B.B. - represents point 96, Paso San José (Laevidentalium? sp.).

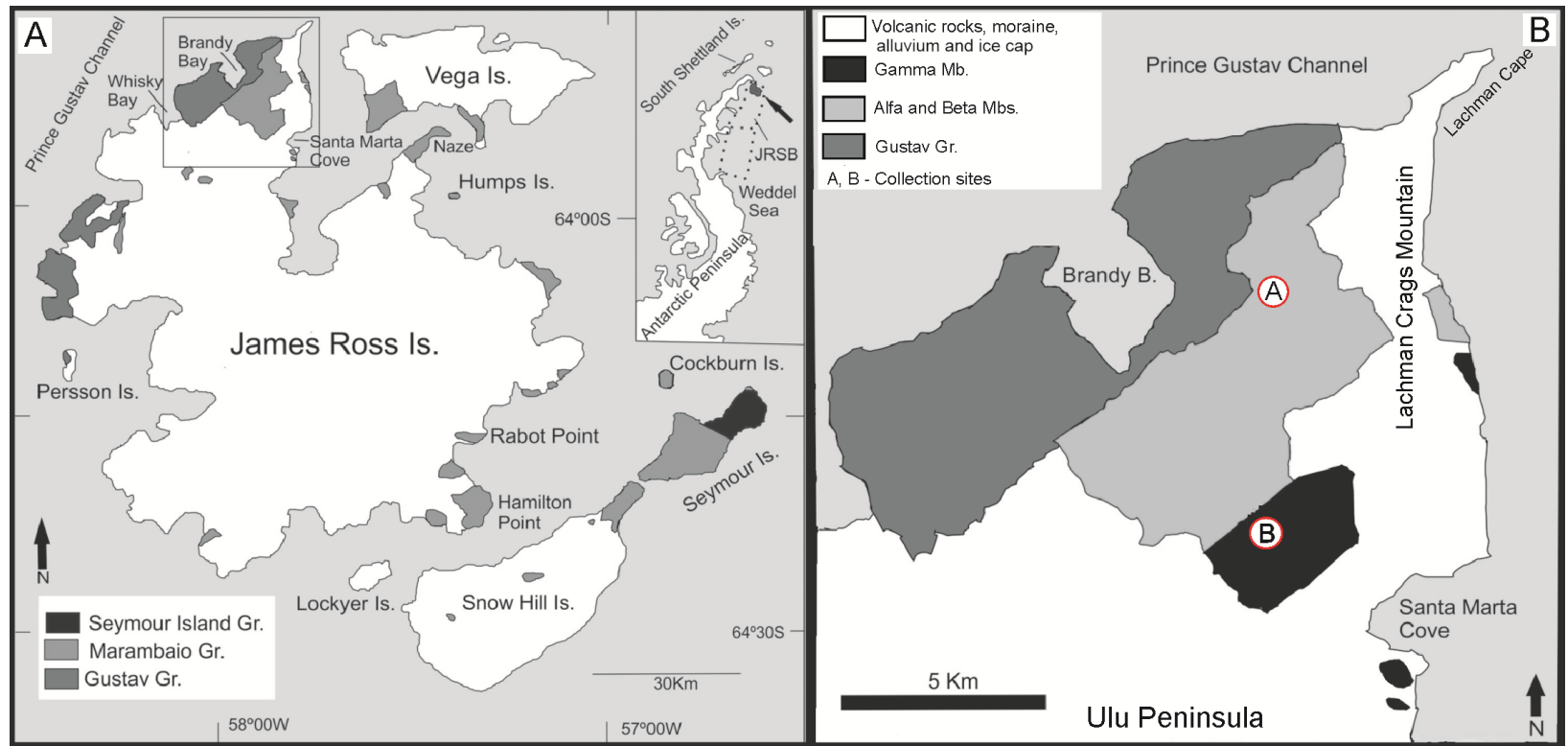

Source: A - adapted from Reguero, Olivero \& Pol (2016); B - adapted from Castro \& Carvalho (2015).

Two thick sedimentary sequences are recognized at the James Ross Island (Olivero, 2012a): the Gustav Group (Aptian - Coniacian) and the Marambio Group (Santonian Danian). The Marambio Group is formed by fossiliferous layers of siltstones, argillites, and fine-grained sandstones, interpreted as being deposited in a shallow inner to outer continental shelf environment with the presence of a prograding delta (Crame et al., 1991; Olivero, 2012a; Pirrie, Crame, Lomas, \& Riding, 1997). Although there are several proposed subdivisions for the Marambio Group (e.g., Olivero, 2012a; Olivero \& Medina, 2000; Pirrie et al., 1997), here the interpretation of Olivero (2012a) is used (Fig. 2). 
Figure 2: Several proposals of subdivisions for the Marambio Group, highlighting the proposal by Olivero (2012a).

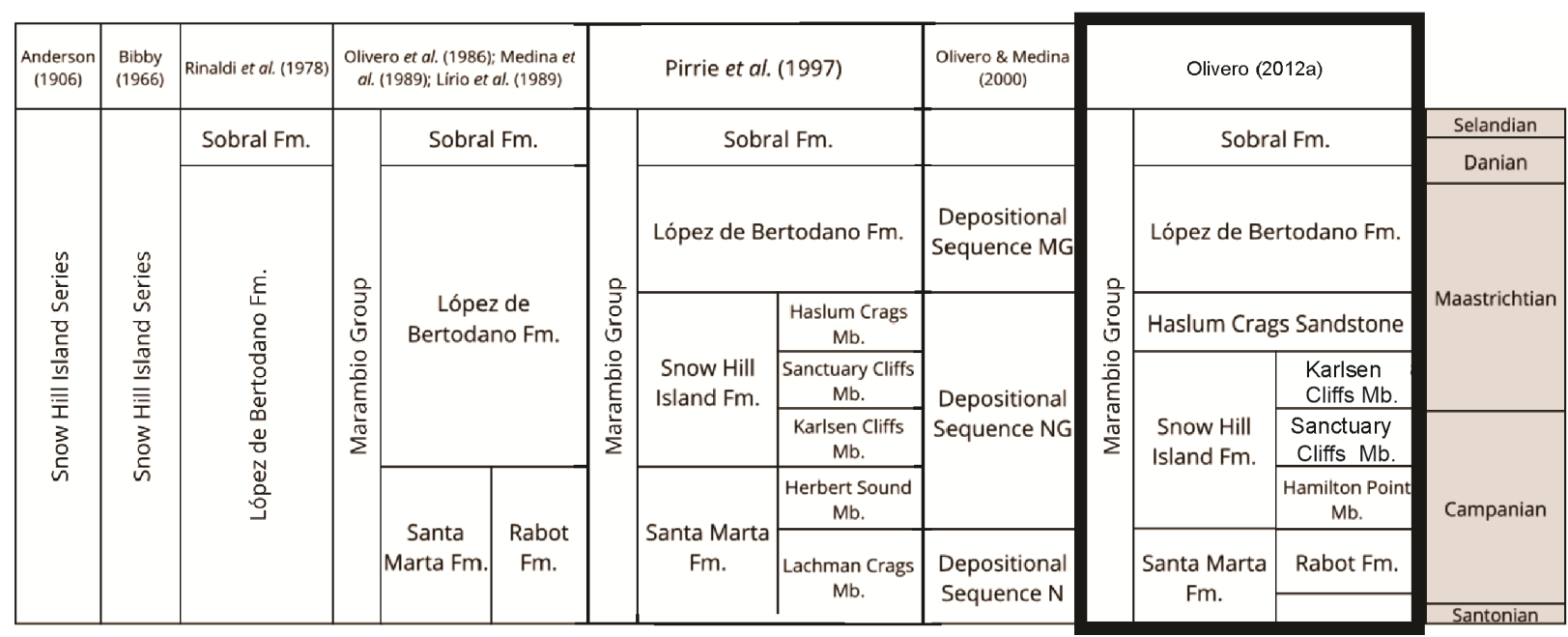

Source: adapted from Milanese, Olivero, Kirschvink \& Rapalini (2017).

\section{Santa Marta and Snow Hill Island (Gamma Member) formations}

The fossils studied in the present contribution were collected in the Santa Marta (Abernethy flats) and Snow Hill Island (Gamma Member, Paso San José) formations (Fig. 3).

The Santa Marta Formation (Santonian - early Campanian) is composed of intercalation of sandstones, siltstones, and argillites with volcanic tuffs and rare coquinas (Olivero, 2012a). It was originally defined at the northwestern area of the James Ross Island and subdivided into Alpha, Beta, and Gamma members by Olivero, Scasso, and Rinaldi (1986).

Olivero (2012a) pointed out that the Gamma Member is included in the Snow Hill Island Formation instead of the Santa Marta Formation, as originally defined. The Gamma Member crops out at Santa Marta Cove and Dreadnought Point and is dominated by sandstones beds with scarce Neograhamites primus ammonites, common gastropods, bivalves, and coquinas (Guerra, Concheyro, Lees, Fauth, Carvalho \& Ramos, 2015).

The Campanian fauna from Santa Marta Formation and Gamma Member are not yet completely known (Crame, 2019), but it is often referred to as part of the Weddellian Biogeographic Province. This province included the seas of New Zealand, South America (Patagonia), and Antarctica from the late Cretaceous to late Eocene (e.g., Novas, D'Angelo, O'Gorman, Agnolín, Lírio, \& Isasi, 2015; Olivero \& Medina, 2000; Zinsmeister 1979, 1982). More recently, Brazilian researchers have made significant progress to the understanding of the invertebrate (e.g., Pinheiro et al., 2020; Videira-Santos et al., 2020) and vertebrate faunas (e.g., Kellner et al., 2011, 2019), nannofossils (Guerra et al., 2015), and dinoflagellate cyst assemblage (e.g., Castro \& Carvalho, 2015) of this stratigraphic unit. 
Figure 3: Sedimentological profile of the Santa Marta and Snow Hill Island formations (Gamma Member) in the Ulu Peninsula. The ammonoid Pseudophyllites? cf. latus was collected from Alpha Member and the scaphopod Laevidentalium? sp. was collected from Gamma Member.

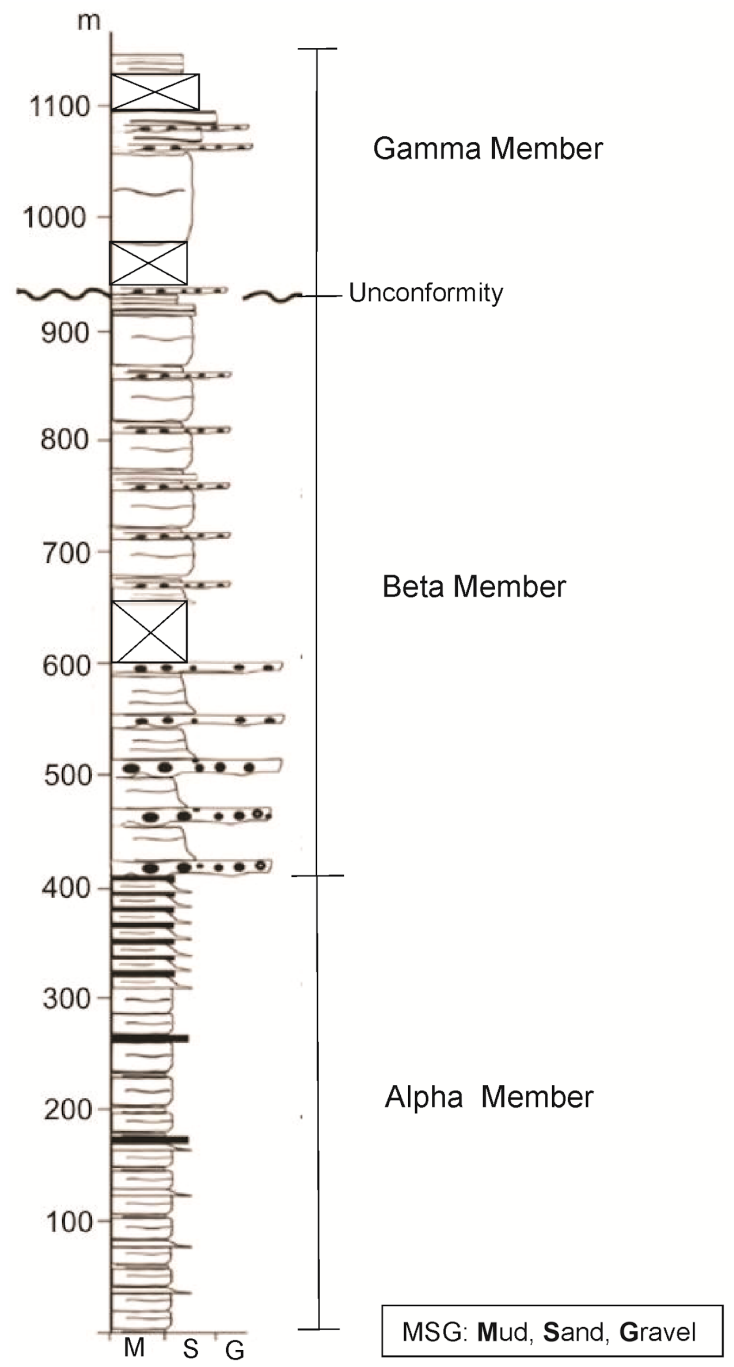

Source: adapted from Olivero (2012b).

\section{MATERIALS AND METHODS}

The studied specimens were collected in the austral summer of 2007 during the expedition to James Ross Island (Ulu Peninsula) carried out by the PALEOANTAR project, led by researchers from the Departamento de Geologia e Paleontologia of the Museu Nacional/Universidade Federal do Rio de Janeiro.

The analyzed fossils are part of the paleoinvertebrate collection housed at the Departamento de Geologia e Paleontologia of the Museu Nacional/Universidade Federal do Rio de Janeiro (MN-I). The specimens studied here were recovered from inside the building of Museu Nacional hit by a tragic fire on September 2, 2018 (Kellner, 2019). The 
Scaphopoda specimen was recovered in relatively good condition, while the material of Ammonoidea was severely damaged.

For taxonomic identification, the Treatise on Invertebrate Paleontology (Knight et al., 1960; Wright, Calloman \& Howarth, 1996) and papers, in general, dealing with ammonoids and scaphopods from Antarctica and related areas such as New Zealand and Australia (e.g., Lamprell \& Healy, 1998) were consulted. For technical terms, dimensions, and morphological descriptions of ammonoids, the procedures outlined by Korn (2010) were used. Specimens were measured with a digital caliper (0.02 $\mathrm{mm}$ accuracy). For open nomenclature identification, we followed the recommendations of Bengtson (1988).

\section{SYSTEMATIC PALEONTOLOGY}

Class Cephalopoda Cuvier, 1795

Order Ammonitida Hyatt, 1889

Suborder Lytoceratina Hyatt, 1889

Superfamily Tetragonitaceae Hyatt, 1900

Family Tetragonitidae Hyatt, 1900

Subfamily Tetragonitinae Hyatt, 1900

Genus Pseudophyllites Kossmat, 1895

Type species: Ammonites indra Forbes, 1846

Pseudophyllites? cf. latus (Marshall, 1926)

(Fig. 4)

Material: MN 8546-I, one internal mold without shell preservation.

Provenance: Alpha Member, Santa Marta Formation, Abernethy flats, field number Point 02 (S 6350'93, $4^{\prime \prime}$ W $057^{\circ} 53^{\prime} 11,0^{\prime \prime}$ ).

Description: subinvolute, weakly depressed, discoidal (whorl width/conch diameter - 0,50), without ribs, the sutures have a strong incision, whorl expansion rate (WER) is extremely high $(>2,50)$. The total diameter of the specimen is $91 \mathrm{~mm}$ (moderate) while that of the umbilical region is $20 \mathrm{~mm}$. The umbilicus/diameter ratio is $22 \%$ (narrow).

Remarks: The genus Pseudophyllites is known in the Santa Marta Formation, but has never been identified at the species level (e.g. Olivero, 1992; Olivero, 2012a). The difference among the species P. latus (Marshall, 1926), P. indra (Forbes, 1846), and P. loryi (Kilian \& Reboul, 1909 ) is very subtle, involving slight differences in the umbilicus/diameter ratio and the shape of the whorl sections. Spath (1953) described P. peregrinus for the Campanian of the Antarctic (Snow Hill Island Series). However, Henderson and McNamara (1985) consider P. peregrinus as synonymous with P. latus, while Macellari (1986) believes that this species is equivalent to P. loryi. The specimen of P. peregrinus described by Spath (1953) is in fact very similar to $P$. latus and $P$. loryi, but its proportion umbilicus/diameter of $16 \%$ makes it more similar to $P$. loryi (on average $18 \%$ ) than to $P$. latus (on average $20 \%$ ) (Henderson \& McNamara, 1985; Macellari, 1986). Based on this information, in this paper, P. peregrinus 
was considered as a junior synonym of $P$. loryi as suggested by Macellari (1986). The specimen MN 8546-I differs from $P$. indra because it has a depressed whorl section and is distinguished from $P$. loryi because it presents a somewhat larger umbilicus/diameter ratio, thus being more evolute. The MN 8546-I specimen does not have very well preserved sutures and neither shows the typical whorl expansion of Pseudophyllites However, we believe that these characteristics have been altered in the studied specimen due to taphonomy. Since the general morphology of the shell is similar to that of Pseudophyllites we advocate classifying our specimen in this genus but with open nomenclature. Among the existing species of Pseudophyllites, the specimen described here is more similar to P. latus.

Occurrence for the species Pseudophyllites latus: late Santonian - early Maastrichtian of Antarctica, Southern Argentina. New Zealand, South-eastern Africa, Madagascar, Western Australia, and Greenland (Henderson \& McNamara, 1985).

Class Scaphopoda Bronn, 1862

Order Dentaliida Da Costa, 1776

Family Laevidentaliidae Palmer, 1974

Genus Laevidentalium Cossmann, 1888

Type species: Dentalium incertum Deshayes, 1825

Figure 4: A: Pseudophyllites? cf. latus (MN 8546-I) (side view), A': Pseudophyllites? cf. latus (MN 8546-I) (frontal view).
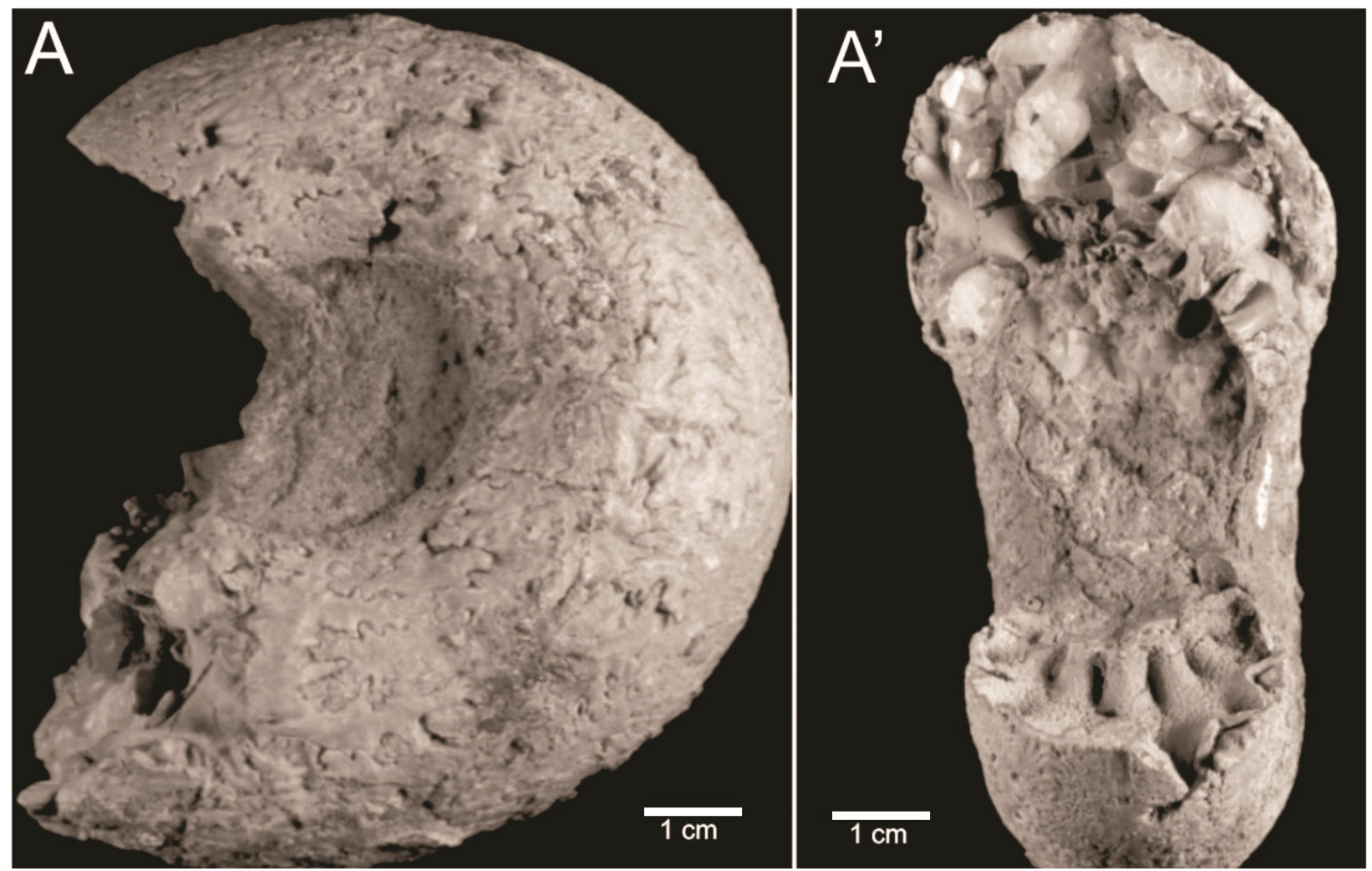


\section{Laevidentalium? sp.}

(Fig. 5)

Material: MN 8608-I, one internal mold with shell preservation.

Provenance: Gamma Member, Snow Hill Island Formation, Paso San José, Point 96 (S63054'16, $8^{\prime \prime} ;$ W057 $\left.54^{\prime} 39,5^{\prime \prime}\right)$.

Description: conical, thick, and weakly curved shell, transverse sections of the aperture and apex ovals, shell tapers uniformly from anterior to posterior, absence of ribs or longitudinal ornaments. The shell is $36 \mathrm{~mm}$ long, with a $5.0 \mathrm{~mm}$ wide aperture and $0.5 \mathrm{~mm}$ wide apex. Remarks: although the specimen is mainly an internal mold, there is a small fragment of the preserved shell (detail of figure 5). From the analysis of this fragment, it is possible to infer that it was relatively thick and did not have longitudinal sculpture. This is corroborated by the fact that the mold itself does not have ribs, which would be reflected in the internal mold. These features support the classification of MN 8608-I to the family Laevidentaliidae (see Lamprel \& Healy, 1998). Although the only known genus of this family is Laevidentalium (Lamprel \& Healy, 1998), since in the studied specimen the shell is not completely preserved, we prefer to classify it with open nomenclature. The only known species of Laevidentalium in the Cretaceous of Antarctica reported so far is Laevidentalium wilckensi from the Lopez de Bertodano Formation, briefly cited by Medina and DelValle (1985). It should be noted, however, that the latter publication is a technical report, and therefore this species (L.wilckensi) should not be considered taxonomically valid.

Occurrence for the genus Laevidentalium in the Cretaceous: Albian, Australia (Stilwell, 2008), Santonian? - Maastrichtian, New Zealand (Stilwell, 2008), Maastrichtian, Chatham Islands (Stilwell, 1998), Maastrichtian, Antarctica (Medina and DelValle, 1985), late Cretaceous, Patagonia (South America) (Stilwell, 2008).

Observation: Laevidentalium is a living genus (e.g., Lamprell and Healy, 1998). 
Figure 5: Laevidentalium ? sp. (MN 8608-I). In detail, we show part of the preserved thick shell without ribs or longitudinal ornamentation.

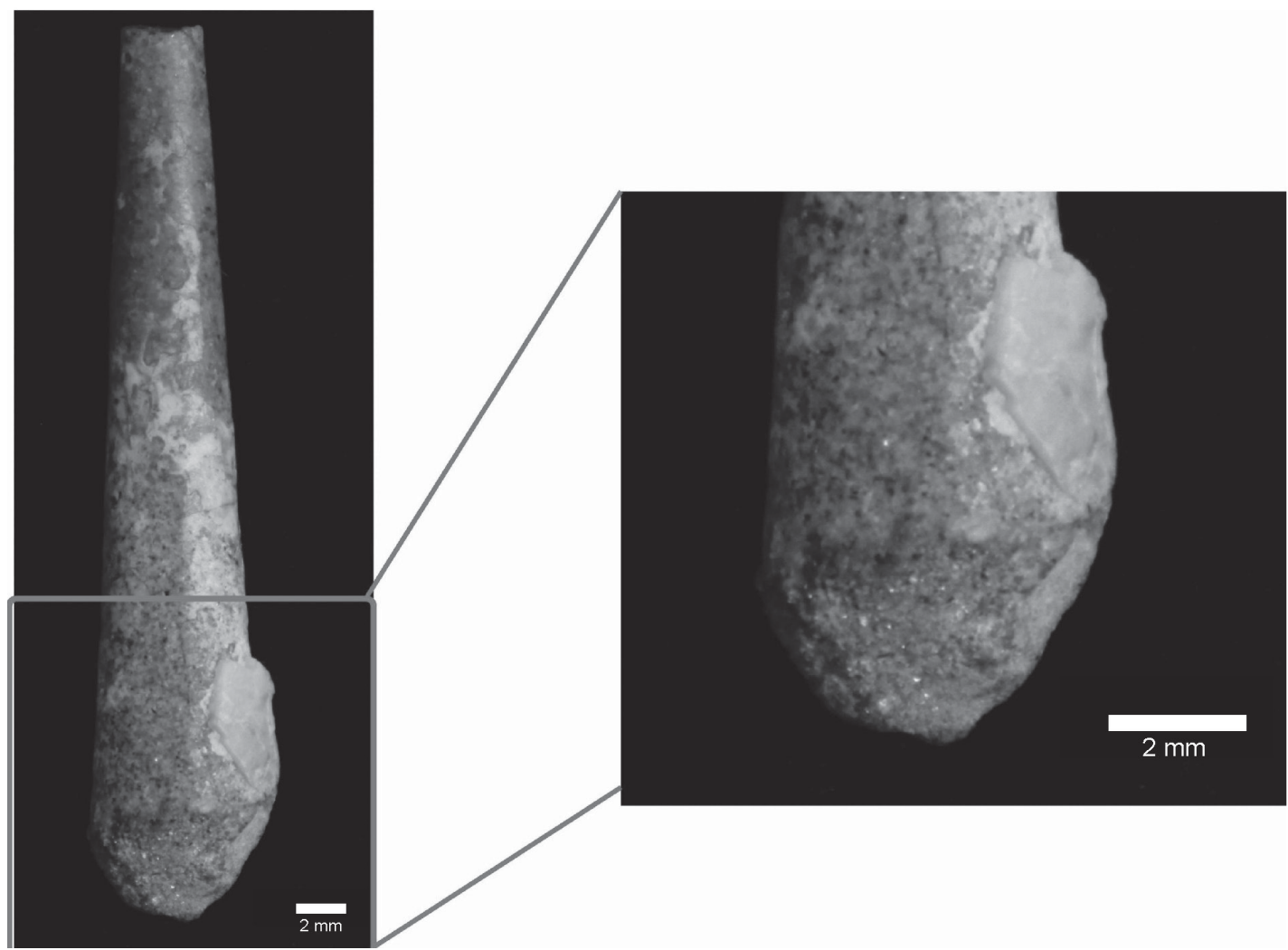

\section{FINAL CONSIDERATIONS}

This paper tries to make the first description of a species of Pseudophyllites from the Santa Marta Formation, considering that Pseudophyllites species of this stratigraphic unit have never been described. However, due to the relatively poor preservation of the specimen, this identification could only be done with open nomenclature. Nonetheless, this specimen shows a higher ammonoid diversity in the Santa Marta Formation.

The taxon Pseudophyllites? cf. latus, known from Santonian - early Campanian beds is not endemic to the Weddelian Biogeographic Province. This species follows the general trend of occurrence of Santonian - early Campanian Antarctic ammonites: a cosmopolitan or Indo-Pacific fauna (Olivero, 2012a; Olivero \& Medina, 2000; Raffi, Olivero, \& Milanese, 2019; Raffi \& Olivero, 2016).

The occurrence of the first specimen of Laevidentaliidae in the Gamma Member of the Snow Hill Island Formation is also reported here. During the Cretaceous, this family was, apparently, restricted to the Southern Hemisphere, in the Weddellian Biogeographic Province. It is represented by the species Laevidentalium cretaustralium recorded in the Albian of Australia (Stilwell, 2008), Laevidentalium sp. from the Cenomanian of Australia (Stilwell, 2008), Laevidentalium morganianum in the ?Santonian to Maastrichtian of New Zealand (Stilwell, 1998; Wilckens, 1922), Laevidentalium wilckensi from the Maastrichtian 
of the Seymour and Snow Hill islands (Antarctica) (Medina \& DelValle, 1985; Stilwell \& Zinsmeister, 1987) and Laevidentalium limatum from the ?Cenomanian to ?Maastrichtian of Patagonia (Stanton, 1901; Stilwell, 2008). The presence of Laevidentalliidae in the late Campanian Gamma Member of Snow Hill Island Formation characterizes, therefore, the oldest occurrence of this family in Antarctica.

The scaphopod specimen studied here (MN 8608-I) was collected in the sequence NG sensu Olivero (2012a) that was deposited in an inner shelf environment, corroborating that the austral scaphopods during the Cretaceous lived in shallow to the mid-shelf environment (Stilwell, 2008).

The family Laevidentaliidae does not currently occur in Antarctica, being restricted to tropical regions (e.g. Almeida \& Oliveira, 2000; Díaz, 1988; Tan, Ang, Nguang, \& Low, 2015). The migration of organisms that lived during the Cretaceous in Antarctica to regions of lower latitudes has been reported in other taxa such as colonial corals (Videira-Santos et al., 2020). This suggests that the members of the family Laevidentaliidae do not tolerate very cold waters, given that the waters in Antarctica began to cool between the late Campanian and the early Maastrichtian (Crame \& Luther, 1997; Dingle \& Lavelle, 1998; Francis \& Poole, 2002; Olivero, 2012a; Pirrie \& Marshall, 1990).

\section{ACKNOWLEDGEMENTS}

This study was supported by Programa Antártico Brasileiro - PROANTAR (CNPq \#557347/2005-0; \#407670/2013-0 and \#442677/2018-9). The authors would like to thank Conselho Nacional de Desenvolvimento Científico e Tecnológico (\#370345/2017-7, CNPq \#313461/2018-0), Fundação Carlos Chagas Filho de Amparo à Pesquisa do Estado do Rio de Janeiro (FAPERJ \#E-26/202.905/2018) and Dr. Renato Ramos (Museu Nacional/ Universidade Federal do Rio de Janeiro) for his help regarding the geological context in which the material studied here was collected.

\section{REFERENCES}

Almeida, M.N., \& Oliveira, M.P. (2000). Lista comentada e ilustrada dos Scaphopoda Brasileiros da Coleção do Setor de Malacologia da Universidade Federal de Juiz de Fora. Revista Brasileira de Zoociências, 2(1), 45-56.

Andersson, J. G. (1906). On the geology of Graham Land. Bulletin of Geology Institute of Uppsala, 7, 19-71.

Bengtson, P. (1988). Open nomenclature. Paleontology, 31(1), 223-227.

Bibby, J.S. (1966). The stratigraphy of part of north-east Graham Land and the James Ross Island group. Britsh Antarctic Survey, Scientific Reports, 53, 1-37.

Bronn, H.G. (1862). Klassen und Ordnungen des Their-Reichs, wissenschaftlich dargestellt in Wort und Bild. Dritter Band, Malacozoa, Erste Abtheilung. Leipzig and Heidelberg: C.F. Wintersche Verlagshandlung.

Castro, S.P., \& Carvalho, M.A. (2015). Santonian dinocyst assemblages of the Santa Marta Formation, Antarctic Peninsula: Inferences for paleoenvironments and paleoecology. Anais da Academia Brasileira de Ciências, 87 (3), 1583-1597. 
Cossmann, M. (1888). Catalogue illustre des coquilles fossiles de I'eocene des environs de Paris: Fast. 3. Annales d' Societe Royale Malacologie Belgique, 23, 3-328.

Crame, J. A. (2019). Paleobiological significance of the James Ross Basin. Advances of Polar Sciences, 30(3), 186-198. Crame, J. A., \& Luther A. (1997). The last inoceramid bivalves in Antarctica. Cretaceous Research, 18(2), 179-195. Crame, J.A., Pirrie, D., Riding, J.B., \& Thomson, M.R.A. (1991). Campanian - Maastrichtian (Cretaceous) stratigraphy of the James Ross Island area, Antarctica. Journal of the Geological Society, 148(6), 1125-1140.

Cuvier, G. (1795). Second Mémoire sur l'organisation et les rapports des animaux à sang blanc, dans lequel on traite de la structure des Mollusques et de leur division en ordre, lu à la société d'Histoire Naturelle de Paris, le 11 prairial an troisième. Magazin Encyclopédique, ou Journal des Sciences des Lettres et des Arts, 2, 433-449.

Da Costa, E.M. (1776). Elements of Conchology or an Introduction to the Knowledge of Shells. London: B. White. DelValle, R.A., Elliot, D.H., \& Macdonald, D.I.M. (1992). Sedimentary basins on the east flank of the Antarctic Peninsula: proposed nomenclature. Antarctic Science, 4(4), 477-478.

Díaz, J. M. (1988). Escafopodos (Mollusca: Scaphopoda) del Caribe Colombiano. Anales del Instituto de Investigaciones Marinas de Punta Betín, 18, 25-37.

Dingle, R., \& Lavelle, M. (1998). Late Cretaceous-Cenozoic climatic variations of the northern Antarctic Peninsula: new geochemical evidence and review. Palaeogeography, Palaeoclimatology, and Palaeoecology, 141(3-4), 215-232.

Forbes, E. (1846). Reports on the Cretaceous fossil invertebrates from southern India, collected by Mr. Kaye and Mr. Cunliffe. Transactions of Geological Society of London, 2(7), 97 - 174.

Francis, J.E., \& Poole, I. (2002). Cretaceous and early Tertiary climates of Antarctica: evidence from fossil wood. Palaeogeography, Palaeoclimatology, and Palaeoecology, 182(1-2), 47-64.

Guerra, R.M., Concheyro, A., Lees, J., Fauth, G., Carvalho, M.A., \& Ramos, R.R.C. (2015). Calcareous nannofossils from the Santa Marta Formation (Upper Cretaceous), northern James Ross Island, Antarctic Peninsula. Cretaceous Research, 56, 550-562.

Hathway, B. (2000). Continental rift to back-arc basin: Jurassic-Cretaceous stratigraphical and structural evolution of the Larsen Basin, Antarctic Peninsula. Journal of the Geological Society, 157, 417-432.

Henderson, R.A., \& McNamara, K.J. (1985). Maastrichtian non-heteromorph ammonites from the Miria Formation, Western Australia. Palaeontology, 28(1), 35-88.

Hyatt, A. (1889). Genesis of the Arietidae. Cambridge: Jonh Wilson and Son.

Hyatt, A. (1900). Cephalopoda In K.A. Zittel (Ed.). Textbook of Paleontology. London: MacMillan.

Kellner, A.W.A. (2019). A reconstrução do Museu Nacional: bom para o Rio, bom para o Brasil. Ciência.e Cultura, 71, 4-5.

Kellner, A.W.A., Simões, T., Riff, D., Grillo, O.N., Romano, P.S.R., Silva, H.P., .. \& Rodrigues, T. (2011). The oldest plesiosaur (Reptillia, Sauropterygia) from Antarctica. Polar Research, 30, 1-6.

Kellner, A.W.A., Rodrigues, T., Costa, F.R., Weinschütz, L.C., Figueiredo, R.G., Souza, ... , \& Sayão J.M. (2019). Pterodactyloid pterosaur bones from Cretaceous deposits of the Antarctic Peninsula. Anais da Academia Brasileira de Ciências, 91, e20191300.

Kilian, W., \& Reboul P. (1909). Les Céphalopodes Néocretaces des îles Seymour etSnow Hill. Wissenschaftliche Ergebnisse der Schwedischen Südpolar-Expedition 1901-1903, 3, 1-75.

Knight, J.B., Cox, L.R., Keen, A.M., Smith, A.G., Batten, R.L., Yochelson, ..., \& Moore, R.C. (1960). Treatise on Invertebrate Paleontology (Part I Mollusca 1: Mollusca General Features, Scaphopoda, Amphineura, Caenogastropoda and Opisthobranchia). Lawrence/ Boulder: Geological Society of America/ The University of Kansas Press.

Korn, D. (2010). A key for the description of Palaeozoic ammonoids. Fossil Record, 13 (1), 5-12.

Kossmat, F. (1895). Untersuchungen über die Südindische Kreideformation. Beitraege zur Paleontologie und Geologie Oesterreich-Ungarns und des Orients, 9, 97-203. 
Lamprell, K.L., \& Healy J.M. (1998). A Revision of the Scaphopoda from Australian waters (Mollusca). Records of the Australian Museum Supplement, 24, 1-189.

Lirio, J.M., Marenssi, S.A., Santillana, S.N., Marshall, P.A., \& Rinaldi, C.A. (1989). Marambio Group at the South eastern part of James Ross Island, Contribución del Instituto Antártico Argentino, 371, 1 - 45.

Macellari, C.E. (1986). Late Campanian-Maastrichtian ammonite fauna from Seymour Island (Antarctic Peninsula). Paleontological Society Memoir, 18, 1-55.

Marshall, P. (1926). The Upper Cretaceous ammonites of New Zealand. The Transactions and Proceedings of the Royal Society of New Zealand, 56, 129-210.

Medina, F.A., \& DelValle R.A. (1985). Scaphopoda (Mollusca) del Cretácico Superior del grupo de islas James Ross, Antártida. Contribucion del Instituto Antártico Argentino, 314, 1-9.

Medina, F.A., Scasso, R.A., DelValle, R.A., Olivero, E.B., Malagnino, E.C., \& Rinaldi C.A. (1989). Cuenca mesozoica del margen nororiental de la peninsula Antártica. In G. Chebli, \& L. Spalleti (eds.), Cuencas sedimentarias argentinas (6 ed., pp. 443-465.). San Miguel de Tucumán: Instituto Superior de Correlación Geologica.

Milanese, F.N., Olivero, E.B., Kirschvink, J.L., \& Rapalini, A.E. (2017). Magnetostratigraphy of the Rabot Formation, Upper Cretaceous, James Ross Basin, Antarctic Peninsula, Cretaceous Research, 72, 172-187.

Novas, F.E., D'Angelo, J.S., O'Gorman, J.P., Agnolín F.L., Lírio J.M., \& Isasi M.P. (2015). First record of Polycotylidae (Sauropterygia, Plesiosauria) from the Upper Cretaceous of Antarctica. Cretaceous Research, 56, 563-568.

Olivero, E. (1992). Asociaciones de ammonites de la Formación Santa Marta (Cretácico tardio), Isla James Ross. In C.A. Rinaldi (ed.), Geología de la Isla James Ross, Antártida (pp. 45-75), Buenos Aires: Contribuciones del Instituto Antártico Argentino.

Olivero, E.B. (2007). Taphonomy of ammonites from the Santonian-Lower Campanian Santa Marta Formation, Antarctica: Sedimentological, controls on vertically embedded ammonites. Palaios, 22, 586-596.

Olivero, E.B. (2012a). Sedimentary cycles, ammonite diversity, and palaeoenvironmental changes in the Upper Cretaceous Marambio Group, Antarctica. Cretaceous Research, 34, 348-366.

Olivero, E.B. (2012b). New Campanian kossmaticeratid ammonites from the James Ross Basin, Antarctica, and their possible relationships with Jimboiceras? antarcticum Riccardi. Revue de Paléobiologie, 11, 133-149.

Olivero, E.B., \& Medina, F.A. (2000). Patterns of Late Cretaceous ammonite biogeography in southern high latitudes: the family Kossmaticeratidae in Antarctica. Cretaceous Research, 21, 269 - 279.

Olivero, E., Scasso, R.A., \& Rinaldi C.A. (1986). Revision del Grupo Marambio en la Isla James Ross Antartida. Contribucion del Instituto Antártico Argentino, 331, 1 - 29.

Palmer, C.P. (1974). The supraspecific classfication of the scaphopod Mollusca. Veliger, 17, 115-125.

Pinheiro, A.P., Saraiva, A.A.F., Santana, W., Sayão, J.M., Figueiredo, R. G., Rodrigues, T., ..., \& Kellner, A.W.A. (2020). New Antarctic clawed lobster species (Crustacea: Decapoda: Nephropidae) from the Upper Cretaceous of the James Ross Island. Polar Research, 39, 3727.

Pirrie, D., Crame, J.A., Lomas, S.A., \& Riding J.B. (1997). Late Cretaceous stratigraphy of the Admiralty Sound region, James Ross Basin, Antarctica. Cretaceous Research, 18(1), 109-137.

Pirrie, D., Crame, J.A., \& Riding J.B. (1991). Late Cretaceous stratigraphy and sedimentology of Cape Lamb, Vega Island, Antarctica. Cretaceous Research, 12, 227- 258.

Pirrie, D., \& Marshall, J. D. (1990). High-paleolatitude Late Cretaceous paleotemperatures: new data from James Ross Island, Antarctica. Geology, 18(1), 31-34.

Pugaczewska, H. (1984). Tertiary Bivalvia and Scaphopoda from glaciomarine deposits at Magda Nunatak, King George Island (South Shetland Islands, Antarctica). Studies in Geology Poland, 29, 53-58.

Raffi, M.E., \& Olivero, E.B. (2016). The ammonite genus Gaudryceras from the Santonian-Campanian of Antarctica: systematics and biostratigraphy. Ameghiniana, 53, 375-396. 
Raffi, M.E., Olivero, E.B., \& Milanese F.N. (2019). The gaudryceratid ammonoids from the Upper Cretaceous of the James Ross Basin, Antarctica. Acta Palaeontologica Polonica, 64 (3), 523-542.

Reguero, M.A., Olivero, E.B., \& Pol, D. (2016). Gondwanan Perspectives: Cretaceous-Paleogene Biota of West Antarctica. Ameghiniana, 53(3), 241-244.

Rinaldi, C.A., Massabie, A., Morelli, J., Rosenman, H.L., \& DelValle, R. (1978). Geologia de la isla Vicecomodoro Marambio. Contribución del Instituto Antártico Argentino, 217, 1-37.

Scasso, R.A., Olivero, E.B., \& Buatois, L.A. (1991). Lithofacies, biofacies, and ichnoassemblage evolution of a shallow submarine volcaniclastic fan-shelf depositional system (Upper Cretaceous, James Ross Island, Antarctica). Journal of South America Earth Sciences, 4(3), 239-260.

Spath, L.F. (1953). The Upper Cretaceous cephalopod fauna of Graham Land. Falkland Islands Dependencies Survey, Scientific Reports, 3, 1-58.

Stanton, T.W. (1901). The marine Cretaceous invertebrates (Part 1, 4 ed.). Stuttgart: Reports of the Princeton University Expeditions to Patagonia.

Stilwell, J.D. (1998). Late Cretaceous Mollusca from the Chatham islands, New Zealand. Alcheringa, 22(1), 29-85.

Stilwell, J.D. (2008). Cretaceous scaphopoda (Mollusca) of Australia and their paleobiogeographic significance. Alcheringa, 23(3), 215-226.

Stilwell, J.D., \& Zinsmeister W.J. (1987). Late Cretaceous fossils from Ula Point, James Ross Island, collected during the 1986-1987 expedition to the Antarctic Peninsula. Antarctic Journal, 22(5), 8-9.

Stilwell, J.D., \& Zinsmeister W.J. (Eds.). (1992). Molluscan Systematics and Biostratigraphy: Lower Tertiary La Meseta Formation, Seymour Island, Antarctic Peninsula (v. 55, Antarctic Research Series). Washington, D.C.: Advancing Earth and Space Science.

Tan, S.K., Ang, H.P., Nguang, L.H.S., \& Low, M.E.Y. (2015). Singapore Mollusca: The family Laevidentallidae (Scaphopoda: Dentaliidae), including a note on the date of the publication of Dentalium incertum Deshaves. Occasional MolluscanPapers, 4, 11-17.

Videira-Santos, R., Scheffler, S.M., Ponciano, L.C.M.O, Weinschutz, L.C., Figueiredo, R.G., Rodrigues, ..., \& Kellner, A.W.A. (2020). First description of scleractinian corals from the Santa Marta and Snow Hill Island (Gamma Member) formations, Upper Cretaceous, James Ross Island, Antarctica. Advances in Polar Sciences, 31(3), 205-214.

Weller, S. (1903a). The Stokes Collection of Antarctic Fossils. Journal of Geology, 11, 413-419.

Weller, S. (1903b). The Stokes Collection of Antarctic Fossils. Contr. Walker Museum, 1, 65-71.

Wilckens, O. (1922). The upper Cretaceous gastropods of New Zealand. New Zealand Geological Survey. Paleontological Bulletin, 9, 1-42.

Wright, C.W., Calloman, J.H., \& Howarth, M.K. (1996). Treatise on Invertebrate Paleontology (Part L, Revised, Mollusca 4: Cretaceous Ammonoidea). Boulder/ Lawrence: Geological Society of America/ The University of Kansas.

Zinsmeister, W.J. (1979). Biogeographic significance of the late Mesozoic and early Tertiary molluscan faunas of Marambio Island (Antarctic Peninsula) to the final break-up of Gondwanaland. In J. Gray, \& A.J. Boucot (Eds.), Historical biogeography, plate tectonics and the changing environment . (pp. 349-355). Corvallis: Oregon State University Press.

Zinsmeister, W.J. (1982). Late Cretaceous - early Tertiary molluscan biogeography of the southern circumPacific. Journal of Paleontology, 56, 84-102.

Data de submissão: 05/abr./2021

Data de aceite: 06/jul./2021 